\title{
EDITH WHARTON
}


Women Writers

General Editors: Eva Figes and Adele King

\section{Published titles:}

Margaret Atwood, Barbara Hill Rigney

Anne Brontë, Elizabeth Langland

Charlotte Brontë, Pauline Nestor

Emily Brontë, Lyn Pykett

Fanny Burney, Judy Simons

Willa Cather, Susie Thomas

Emily Dickinson, Joan Kirkby

Sylvia Plath, Susan Bassnett

Christina Stead, Diana Brydon

Eudora Welty, Louise Westling

Edith Wharton, Katherine Joslin

Women in Romanticism, Meena Alexander

\section{Forthcoming}

Jane Austen, Meenakshi Mukherjee

Elizabeth Barrett Browning, Marjorie Stone

Elizabeth Bowen, Phyllis Lassner

Ivy Compton Burnett, Kathy Gentile

George Eliot, Kristin Brady

Mrs Gaskell, Jane Spencer

Katherine Mansfield, Diane DeBell

Christina Rossetti, Linda Marshall

Jean Rhys, Carol Rumens

Muriel Spark, Judith Sproxton

Gertrude Stein, Jane Bowers

Virginia Woolf, Clare Hanson

Further titles are in preparation 


\section{Women Writers}

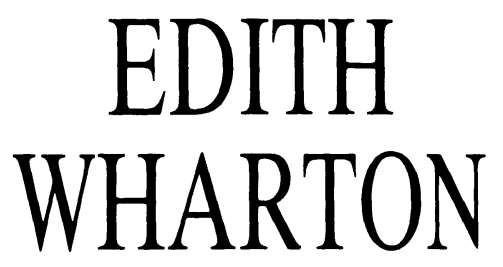

Katherine Joslin

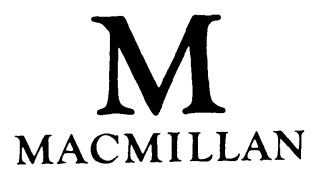


(C) Katherine Joslin 1991

All rights reserved. No reproduction, copy or transmission of this publication may be made without written permission.

No paragraph of this publication may be reproduced, copied or transmitted save with written permission or in accordance with the provisions of the Copyright, Designs and Patents Act 1988 or under the terms of any licence permitting limited copying issued by the Copyright Licensing Agency, 33-4 Alfred Place, London WC1E 7DP.

Any person who does any unauthorised act in relation to this publication may be liable to criminal prosecution and civil claims for damages.

First published 1991

Published by

MACMILLAN EDUCATION LTD

Houndmills, Basingstoke, Hampshire RG21 2XS

and London

Companies and representatives

throughout the world

Typeset by BP Integraphics. Bath, Avon

British Library Cataloguing in Publication Data

Joslin, Katherine

Edith Wharton. - (Women writers)

1. Fiction in English. American writers. Wharton, Edith 1862-1937

I. Title II. Series

813.52

ISBN 978-0-333-40730-1

ISBN 978-1-349-21323-8 (eBook)

DOI 10.1007/978-1-349-21323-8 


\section{Contents}

Editors' Preface

vi

Acknowledgements

vii

1 Edith Wharton's Life 1

2 Edith Wharton's Fiction 28

3 The House of Mirth and the Question of Women

49

4 The Custom of the Country and the Atlantic's Call

5 The Age of Innocence and the Bohemian Peril

89

6 The Mother's Recompense: Spectral Desire

108

7 Edith Wharton and the Critics

Notes

Bibliography

151

Index 


\section{Editors' Preface}

The study of women's writing has been long neglected by a male critical establishment both in academic circles and beyond. As a result, many women writers have either been unfairly neglected or have been marginalised in some way, so that their true influence and importance has been ignored. Other women writers have been accepted by male critics and academics, but on terms which seem, to many women readers of this generation, to be false or simplistic. In the past the internal conflicts involved in being a woman in a male-dominated society have been largely ignored by readers of both sexes, and this has affected our reading of women's work. The time has come for a serious reassessment of women's writing in the light of what we understand today.

This series is designed to help in that reassessment.

All the books are written by women because we believe that men's understanding of feminist critique is only, at best, partial. And besides, men have held the floor quite long enough.

Eva Figes

Adele King 


\section{Acknowledgements}

Many organizations and people have assisted me in my work on Edith Wharton. I am grateful to the Alumnae of Northwestern University for a fellowship that allowed me to travel to the Beinecke Library at Yale University to read Wharton's papers and to the staff at the Beinecke for their assistance in locating material. I am also grateful to Western Michigan University for a Faculty Research Support Grant that gave me time to complete this book. Many members of the Edith Wharton Society have also helped to guide my research and thinking about Wharton; I thank them all.

Individually, I would like to thank Carl Smith, Harriet Gilliam, and especially Harrison Hayford at Northwestern University for their reading of early drafts of my material and Edward Galligan and Clare Goldfarb at Western Michigan University for their advice on sections of my later work. The comments and suggestions of Eva Figes and Adele King have greatly helped me give shape to my argument. I thank them both for their work.

My special thanks go to my husband and colleague Thomas Bailey, whose culinary creations, no less than his literary insights, have sustained my work. 
To my daughter Emily 